\title{
Analysis of the Impact of Managerial Ownership, Institutional Ownership, Firm Size, Leverage, Profitability and Sales Growth Toward Earnings Management in Manufacturing Companies Listed on IDX in the 2015-2019 Period
}

\author{
Sella Herlina Harahap \\ sella.herlina20@gmail.com \\ Pelita Harapan University, Surabaya, Indonesia
}

\begin{abstract}
The phenomenon of earnings management is very interesting to research because it can provide an overview of the behavior of managers in reporting their business activities in a certain period, namely the emergence of earnings management caused by managers by manipulating company profits to be higher, lower, or always the same for several periods. Certain motivations encourage them to manage or manage financial data, especially reported earnings. This study aims to analyze a model regarding the effect of Managerial Ownership, Institutional Ownership, Firm Size, Profitability (ROA), Leverage (DER), and Sales Growth toward Earnings Management in Manufacturing Companies listed on the IDX in the 2015-2019 period.

The type of non-probability sampling used in this study is purposive sampling because the sampling technique is based on certain considerations. Certain considerations in determining the sample or respondent in this study are manufacturing companies that are consistently listed on the IDX website during the 2015-2019 period and companies that have managerial and institutional share ownership data respectively during the observation period. The number of samples (N) used was 285 data obtained from 57 manufacturing companies with a 5year study period.

The result of the study concludes that Managerial Ownership, Institutional Ownership, Company Size, and Leverage (DER) do not affect Earnings Management. Meanwhile, Profitability (ROE) and Sales Growth have a significant positive effect on Earning Management.
\end{abstract}

Keywords: Earnings Management; Managerial Ownership; Institutional Ownership; Firm Size; Leverage; DER; Profitability; ROE; Sales Growth.

\section{Introduction}

Over time, economic and business development is now increasingly rapid. Fierce competition in the business world today encourages companies to compete competitively with advantages in their respective sectors. Through the use of available company resources effectively and efficiently in carrying out operational activities, can be one of the factors for companies to increase the company's competitiveness against the market. Besides, attracting and or retain several investors to support company activities is becoming increasingly difficult due to the tight competition. Therefore, companies tend to always show good performance. One of the measuring tools that can be used to determine the company's performance is the amount of profit earned. Profit figures that continue to increase from year to year can be assumed that the 
company can manage its resources maximally to make a profit.

Financial reports are the main consideration for users to make decisions, therefore, financial reports must be displayed correctly under applicable financial accounting standards. The general purpose of financial reports is to provide financial statement users with information about the company's financial position, performance, and cash flow to use as a basis for decision making and to demonstrate management's responsibility for the use of resources entrusted to them.

Phenomena that often occur related to earnings management usually caused by errors and omissions of the financial management entity itself, which are directly or indirectly influenced by various internal and external factors. Related to the agency theory, Jensen \& Meckling (1976) states that an agency relationship is a manager (agent) contract with shareholders (principal). Both parties are bound by a contract that defines the rights and obligations of each party. Principals provide facilities and resources to conduct business, while agents are required to manage what shareholders entrust to them. Separation of ownership and control results in differences in interests between shareholders as owners and managers as controllers. Managers have a responsibility to maximize the welfare of shareholders and debtholders, but on the other hand, managers also have an interest in maximizing their welfare. This unification of the interests of the parties often creates problems known as agency conflict. Earnings management is one of the agency problems that occur because of the separation of ownership and control between shareholders and company management.

Earnings management is a condition for the management to intervene in the preparation of financial reports for external parties so that they can increase, stabilize and decrease earnings (Schipper, 1989). Healy and Wahlen (1999) show that earnings management occurs when management uses certain decisions in the financial statements and prepares transactions that change the financial statements. Therefore, it is intended to mislead users of financial statements about the company's economic situation and affect the contractual income that can control the accounting numbers reported.

One of the factors that influence earnings management is managerial ownership. Theoretically, the management who has a high percentage of share ownership will act like someone who holds an interest in the company. This assumption is in line with the contracting based theory which shows that management will be efficient in choosing accounting methods that will provide added value to the company (Christie \& Zimmerman, 1994). The parties involved in the contract will review the managers who own the company's shares, such as selecting an audit committee that will ask shareholders, creditors, and users of financial reports to provide high-quality financial reports to ensure the efficiency of the contracts being made. Management will be motivated to prepare quality financial reports. This will reflect better contract conditions (Ball, Robin, $\& \mathrm{Wu}, 2003)$. Therefore, it is likely that the level of managerial ownership will be in the same direction to suppress management's utilization of earnings management. Research (Kouki, Abderrazek, Hanen, \& Slim, 2011) reveals that managerial ownership has a negative effect on earnings management. Meanwhile, according to research (Asih, 2015), managerial ownership has a significant positive effect on earnings management practices.

Institutional ownership is considered to provide a similar monitoring mechanism within the company. Research (Widyastuti, 2009) shows that institutional ownership has a negative and significant impact on earnings management. This shows that institutional ownership can minimize the possibility of earnings management because institutional investors can supervise and are not easily fooled by manager behavior. Meanwhile, research conducted by (Jao \& Pagalung, 2011) shows that institutional ownership has a positive and significant effect on earnings management, which means that an increase in institutional ownership will also increase earnings management actions in the company.

Firm size can be a factor in the occurrence of earnings management in the company. There are two views about the firm size on earnings management. The first view is that small company sizes are considered to be more likely to practice earnings management than large companies. It is because small companies tend to have the ambition to show the investors that the company is performing well. Meanwhile, large companies care more about the public, so they will be more careful in financial reporting so that the impact on these 
companies is to report their status more accurately (Nasution \& Setiawan, 2007). The second view in proprietary research (Watts \& Zimmerman, 1990) states that compared to small firms, large firms have greater motivation for income smoothing (earnings management) because large firms have greater political costs. Political costs arise because of the high profitability of the company, which can attract the attention of the media and consumers. However, regarding these two views, both state that company size has a positive influence on earnings management.

Another component that can be used as an assessment of company performance by external parties is leverage. The greater the Leverage ratio, the higher the company's debt. Firth \& Smith (1992) stated that the greater the debt owed by the company; the tighter supervision carried out by creditors. This results in reduced management flexibility to perform Earnings Management. This means that the higher the leverage ratio, the lower the possibility for management to do earnings management. Almadara (2017) in his research revealed that the leverage variable has a negative effect on earnings management. This is in line with research conducted by Mahiswari \& Nugroho (2014). Meanwhile, research conducted by (Dechow, Sloan, \& Sweeney, 1996) found that the company's motivation for earnings management is to meet external capital needs and fulfill debt covenants. Sari's research (2015) shows that leverage has a positive effect on earnings management. A positive coefficient indicates that high leverage encourages company management to manage earnings to avoid violating debt contracts. Meanwhile, different results were found in Indriyani's (2010) research which examined the effect of leverage on earnings management in banking companies on the IDX, that leverage does not have a significant effect on earnings management. This is because the high debt policy causes the company to be monitored by debtholders (third parties). Because the tight monitoring in the company causes managers to act in accordance with the interests of debtholders and shareholders.

Another variable that can affect earnings management is Profitability. The effectiveness of the company in generating profits through the operation of assets owned is a benchmark for company performance and can also motivate earnings management actions in the company. The greater the Return on Assets as a profitability ratio, the more efficient the use of assets will be so that it will increase the company's profitability. Big profits will attract investors because with large profits the company will have a higher rate of return. The higher this ratio, the better the asset productivity in obtaining net profit. So that Return on Assets can motivate management to carry out earnings management, and it can also be said that Return on Assets has a positive effect on earnings management, such as research conducted by Guna and Herawaty (2010) which shows that profitability has a significant positive effect on earnings management. The opposite results were obtained by Purwandari's (2011) study which states that Return on Assets has a significant negative effect on earnings management actions.

Companies with high sales growth rates also have the motivation to carry out earnings management to earn profits, when they are faced with problems to maintain profit trends and sales trends. This makes sales growth can affect the existence of earnings management. Research conducted by Nayiroh (2013) states that sales growth does not affect earnings management. While the results of research conducted by Handayani and Rachadi (2009) and Sari (2015) state that sales growth has a positive effect on earnings management.

Manufacturing companies are more widely used as research subjects because manufacturing companies listed on the IDX (Indonesia Stock Exchange) have various industrial subsectors, which can reflect the reaction of the capital market as a whole. Besides, manufacturing companies also have the largest number of companies on the Indonesia Stock Exchange compared to other corporate sectors.

\section{Review of Related Literature}

Jensen \& Meckling (1976) states that an agency relationship is a manager (agent) contract with shareholders (principal). Both parties are bound by a contract that defines the rights and obligations of each party. Principals provide facilities and resources to conduct business, while agents are required to manage 
what shareholders entrust to them. Separation of ownership and control results in differences in interests between shareholders as owners and managers as controllers. Managers have a responsibility to maximize the welfare of shareholders and debtholders, but on the other hand, managers also have an interest in maximizing their welfare. This unification of the interests of the parties often creates problems known as agency conflict.

Govindarajan (2009) states that one key element of agency theory is that principals and agents have different preferences and goals. Agency theory assumes that all individuals act in their best interests.

According to Scott (2000), agency theory is the design of an appropriate contract to align the interests of principals and agents in the event of a conflict of interest. Agency problems arise when the principal finds it difficult to ensure that the agent acts to maximize the principal's welfare (Yushita, 2010).

Eisenhardt (1989) states that agency theory uses three assumptions of human nature, namely, humans are generally self-interested, humans have limited thinking power about future perceptions (bounded rationality), and humans always avoid risk (risk-averse).

This study uses the discretionary accrual calculation of the Modified Jones model. The following proxies according to Dechow, Sloan, Sweeney (1995):

$$
\text { TACC }_{i t}=N I_{i t}-C F O_{i t}
$$

Where:

TACCit $=$ Total Accrual $\mathrm{i}$ in year $\mathrm{t}$

NIit $=$ Net Income $\mathrm{i}$ in year $\mathrm{t}$

CFOit = Company $\mathrm{i}$ 's operating cash flow in year $\mathrm{t}$

To find out the value of non-discretionary accruals, it is necessary to calculate the coefficient of the accrual regression which is known by regression as follows:

$$
\frac{T A C C_{i t}}{T A_{i t-1}}=\alpha\left(\frac{1}{T A_{i t-1}}\right)+\beta 1\left[\frac{\Delta R E V_{i t}}{T A_{i t-1}}\right]+\beta 2\left(\frac{P P E_{i t}}{T A_{i t-1}}\right)+\varepsilon_{i t}
$$

Where:

TACCit $=$ Total Accrual $\mathrm{i}$ in year $\mathrm{t}$

TAit-1 = Total Assets i in year $\mathrm{t}-1$

$\triangle \mathrm{REVit}=$ Change in net income of firm $\mathrm{i}$ between year $\mathrm{t}$ and year $\mathrm{t}-1$

$\triangle \mathrm{RECit}=$ Change in the receivables of company $\mathrm{i}$ between year $\mathrm{t}$ and year $\mathrm{t}-1$

PPEit $=$ The acquisition value of fixed assets at company $i$ in year $t$

$\varepsilon$ it $=$ Error term

The total accrual equation above was estimated using the Ordinary Least Square (OLS) method. Estimates of $\alpha, \beta 1, \beta 2$ were obtained from the OLS regression and used to calculate the Non-Discretionary Accrual as follows:

$$
N D A C C_{i t}=\alpha\left(\frac{1}{T A_{i t-1}}\right)+\beta 1\left[\frac{\Delta R E V_{i t}}{T A_{i t-1}}-\frac{\Delta R E C_{i t}}{T A_{i t-1}}\right]+\beta 2\left(\frac{P P E_{i t}}{T A_{i t-1}}\right)+\varepsilon_{i t}
$$

After regressing the above model, Discretionary Accrual can be calculated by the equation:

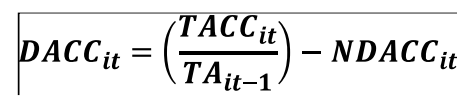




\subsection{Managerial Ownership}

Managerial ownership, namely ownership of shares of a company by management. Earnings management is largely determined by the motivation of the company manager. Low share ownership, then the incentive for the possibility of opportunistic behavior of managers will increase (Shleifer and Vishny, 1986).

According to Downes and Goodman (1999), managerial ownership is the management who is the shareholder of the company, in this case, the management (directors and commissioners) is also the owner of the company who actively participates in making company decisions. Therefore, management plays an important role as they carry out planning, organization, guidance, monitoring, and decision making.

Research (Kouki et al. 2011) reveals that managerial ownership has a negative effect on earnings management and can improve the quality of the financial reporting process, this is because when managers also have a share of ownership, they will act the same as general shareholders and ensure that financial reports have been fairly presented and disclosed the real condition of the company.

The results of research by Midiastuty and Machfoedz (2003), Ujiyantho and Pramuka (2007), Ali et al. (2008), Jao (2014), Mahariana and Ramantha (2014), and Sari (2015) also found that managerial ownership has a negative relationship with earnings management. Based on the results of several studies above, it can be concluded that the greater the managerial ownership, the lower the earnings management behavior.

H1: Managerial ownership has a negative effect on earnings management.

\subsection{Institutional Ownership}

Institutional investors have the opportunity, resources, and ability to supervise, discipline, and influence company managers in terms of opportunistic management actions (Chung et al. In Purwandari, 2011). Institutional investors who have large shareholdings will have a strong enough incentive to gather information, supervise and encourage better management performance. If institutional investors have a relatively lower number of shareholdings, then institutional investors have little incentive to oversee the opportunistic actions of managers.

According to Tarjo (2008), institutional ownership is the ownership of company shares owned by other institutions or companies (such as insurance companies, banks, investment companies, and other institutional ownership). Institutional ownership means very important in supervision and management because the existence of institutional ownership will best encourage the strengthening of supervision. This kind of Supervision will certainly guarantee the prosperity of shareholders, and the influence of institutional ownership as a supervisory agency will be suppressed by massive investment in the capital market.

The results of research conducted by Balsam et al. (2002) stated that high institutional ownership can minimize earnings management practices, but depending on the significant number of ownerships so that it will be able to monitor management which has an impact on reducing managers' motivation to carry out earnings management. The results of research by Rajgofal et al. (1999), Midiastuty and Mahfoedz (2003), Cornett et al. (2006), Tarjo (2008), Shah et al. (2009), Jao (2011), and Sari (2015) also found that institutional ownership has a negative relationship with earnings management.

H2: Institutional ownership has a negative effect on earnings management. 


\subsection{Firm Size}

Company size can be defined as the effort to assess the size of a company. The size of the company will be very important for investors and creditors because it will relate to the investment risk being made. Companies with medium and large sizes have more pressure than their stakeholders so that the company's performance is in line with the expectations of its investors compared to small companies.

Moses (1997) argues that larger companies have a greater incentive to smooth income (a form of earnings management) compared to small companies because large companies have greater political costs.

Large companies will receive more public attention, so they will be more careful in terms of financial reporting and reporting conditions. Company size is measured using the natural logarithm of total assets owned by the company (Jao \& Pagalung, 2011)

Political costs arise because high company profitability can attract media and consumer attention. Research results according to Halim (2005), Nuryaman (2008), Llukani (2013), Asih (2014) and Putra et al. (2014) stated that company size has a significant positive effect on earnings management practices.

H3: Firm size has a positive effect on earnings management

\subsection{Leverage}

According to (Irawati, 2006), leverage is a policy carried out by a company in terms of investing funds or obtaining sources of funds accompanied by fixed expenses that the company must bear.

According to (Fakhruddin, 2008), leverage is the amount of debt used to finance/purchase company assets. Companies that have debt greater than equity are said to be companies with a high degree of leverage.

Leverage Ratio or Solvency Ratio or Debt Ratio is a comparison used to measure how much a company's debt loans are financed by the assets (assets) and equity (capital) owned by the company. According to Van Horne (2002: 357), the Leverage Ratio is a ratio that describes the proportion of corporate debt. Research conducted by Saleh et al. (2005), Tarjo (2008), and Lin et al. (2009) found that leverage has a positive relationship with earnings management.

Leverage is the ratio between total liabilities and total equity. The greater the leverage ratio, the higher the company's debt value. A company that has a high leverage ratio means that the proportion of debt is higher than the proportion of its assets, so the supervision carried out by creditors on the company will be tighter. The results in reduced management flexibility to perform Earnings Management. It means that the higher the leverage ratio, the lower the possibility for management to do earnings management. Almadara (2017) in his research revealed that the leverage variable has a negative effect on earnings management. It is in line with research conducted by Mahiswari \& Nugroho (2014).

H4: Leverage has a negative effect on earnings management.

\subsection{Profitability}

Profitability shows the ability of management to generate profits by utilizing assets used in operating activities. Bonus Plan The hypothesis states that if in a certain year the actual performance is below the requirements for getting a bonus, the manager will carry out earnings management so that the profit can reach the minimum level to get the bonus. Concerning earnings management, profitability can influence managers to carry out earnings management. Because the profitability obtained by the company is low, in general managers will take earnings management actions to save their performance in the eyes of the owner. 
According to Weygandt et al. (1996), the profitability ratio is the ratio used to measure the effectiveness of the company's management as a whole, which is indicated by the amount of profit the company receives. Profitability ratios are considered as the most valid tool in measuring the results of the company's operations because profitability ratios are comparison tool for various investment alternatives according to the level of risk. The greater the investment risk, the higher the profitability is expected.

Return on Assets (ROA) is part of the profitability ratio analysis. Return on Asset is the ratio between net income which is inversely proportional to the total assets to generate profit. Kasmir (2012: 201) explains that Return on Assets is a ratio that shows the results (return) on the total assets used in the company. In other words, Return on Assets (ROA) can be defined as a ratio that shows how much net profit can be obtained from all the wealth owned by the company.

This statement is supported by research by Welvin and Arleen (2010) showing the results that profitability has a positive effect on earnings management.

H5: Profitability has a positive effect on earnings management.

\subsection{Sales Growth}

Sales growth shows an increase in sales from year to year. If sales and profits increase every year, then financing debt with a certain fixed expense will increase shareholder income. Therefore, managers are encouraged to carry out earnings management in line with the higher sales growth of a company so that the company's profits appear to be lower than the actual profit obtained. Companies can predict how much profit will be obtained by the amount of sales growth. According to Perdana (2013), sales growth in a company shows that the greater the sales volume, the higher the profit that will be generated. Sales growth is defined as an increase in the number of sales over time or from year to year (Kennedy, 2010)

According to Fahmi (2012: 69), the growth ratio is a ratio that measures how much the company's ability to maintain its position in the industry and general economic development. This growth ratio is seen from various aspects of sales (sales), earning after tax (EAT), earnings per share, dividends per share, and market price per share.

This statement is supported by the research of Gu et al. (2005), Handayani and Rachadi (2009), and Sari (2015) which state that sales growth has a positive effect on earnings management.

H6: Sales growth has a positive effect on earnings management

\section{Research Methodology}

This research will be directed to analyze models regarding the influence of Managerial Ownership, Institutional Ownership, Company Size, Profitability (ROA), Leverage (DER), and Sales Growth on Profit Management in Manufacturing Companies in 2015-2019 listed on the IDX. The theoretical framework and model will be used as the theoretical basis for this research. 


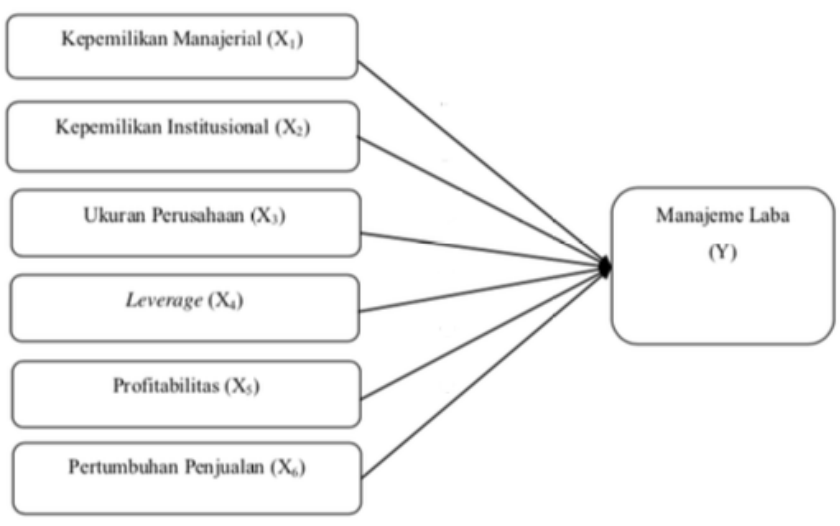

Fig. 1. Research methodology

The method used in this research is quantitative. According to Sugiyono, quantitative research methods can be interpreted as research methods based on the philosophy of positivism, used to research on a particular population or sample. The sampling technique is generally carried out randomly, data collection using research instruments, quantitative/statistical data analysis to test predetermined hypotheses (Sugiyono, 2012). The purpose of this study is to explain, explain the generalization of the sample for the population, or explain the relationship, difference, or influence between one variable and another (Bungin, 2008). Based on the benefits of research, this research is basic research or basic research because this study aims to find new knowledge about fundamental phenomena (Sugiyono, 2012), namely to determine the role of Managerial Ownership, Institutional Ownership, Company Size, Profitability (ROA), Leverage (DER) and Sales Growth to Profit Management in Manufacturing Companies listed on the IDX in the 2015-2019 period (idx.com).

The population is a generalization area consisting of objects/subjects that have certain qualities and characteristics that are determined by the researcher for the study and then draw conclusions. (Sugiyono P. D., 2017). The population used in this study is non-banking companies, namely manufacturing companies listed on the IDX in the 2015-2019 period. Based on the stock list data listed on the IDX website, there are a total of 3 sectors and 20 subsectors of manufacturing companies (Indonesia Stock Exchange, 2020)

The sampling technique used in this study is non-probability sampling because the sampling technique does not provide equal opportunities for each element or member of the population to be selected as samples (Sugiyono, 2014). The type of non-probability sampling used in this study is purposive sampling because the sampling technique is based on certain considerations (Sugiyono, 2014). Certain considerations in determining the sample or respondent in this study are manufacturing companies that are consistently listed on the IDX website during the 2015-2019 period, companies that have consecutive managerial share ownership data during the observation period, companies that have consecutive institutional share ownership data. During the observation period, companies that have managerial and institutional share ownership data respectively during the observation period. 
Table 1. Sample Planning

\begin{tabular}{lll}
\hline No. & \multicolumn{1}{c}{ Characteristics } & Total \\
\hline 1. & $\begin{array}{l}\text { Manufacturing companies consistently listed on the IDX } \\
\text { website during the 2015-2019 period }\end{array}$ & 144 \\
2. & $\begin{array}{l}\text { Companies that do not have managerial and institutional share } \\
\text { ownership data respectively during the observation period. }\end{array}$ & $(87)$ \\
& $\begin{array}{l}\text { Total Sample } \\
\text { Total Sample 5-years period }\end{array}$ & 57 \\
\hline
\end{tabular}

The data collection method used in this study is to use the non-participant observation method in the form of financial statements of manufacturing companies in the consumer goods industry sector which are listed on the Indonesia Stock Exchange (IDX) during the study period, which is obtained from the official website of the IDX. Quantitative data is divided into discrete data and continuum data. Continuum data is divided into ordinal data, interval data, and ratio data (Sugiyono, 2015). This study using ratio data. Data collection is an important part of research (Darmono and Hasan, 2002). The data used in this research is secondary data. The secondary data collection technique used in this study is data collection from the financial and annual reports of manufacturing companies on the IDX website. The type of data in this study is ratio data. According to the classification of collection, the type of data is cross-section data, namely in the 2015-2019 period.

Data analysis methods in this study include descriptive statistics, data quality test factor analysis, multiple linear regression analysis, and hypothesis testing. Test data quality using the classic assumption test which includes normality test, multicollinearity test, heteroscedasticity test, and autocorrelation test. Hypothesis testing used is the t-test and F test. This analysis tool uses the SPSS version 22.0 program.

\section{Result of the Study}

\section{Multiple Linear Regression Analysis}

Multiple linear regression analysis determines the linear relationship between a single dependent variable and multiple independent variables by estimating the regression coefficient for straight line equations.

Table 2. Results of Multiple Linear Regression Analysis

\begin{tabular}{|l|c|}
\hline \multicolumn{1}{|c|}{ Variable } & Coefficients \\
\hline Constant & 0,000260 \\
\hline Managerial Ownership & $-0,065$ \\
\hline Institutional Ownership & $-0,011$ \\
\hline Firm Size & 0,006 \\
\hline Leverage (DER) & $-0,007$ \\
\hline Profitability (ROA) & 0,196 \\
\hline Sales Growth & 0,188 \\
\hline
\end{tabular}

The coefficient which is positive shows changes in the direction of the independent variable against the dependent variable, while the coefficient that is negative shows the opposite change between the independent variable and the dependent variable. 
The Coefficient of determination $\left(\mathrm{R}^{2}\right)$

Table 3. Result of Determination Coefficient Analysis

\begin{tabular}{|c|c|}
\hline R-Squared & Adj. R-Squared \\
\hline 0,090 & 0,070 \\
\hline
\end{tabular}

The coefficient of determination $\left(\mathrm{R}^{2}\right)$ in essence measures how far the model's ability to explain the variation in the dependent variable. The coefficient of determination is between zero and one. The small value of $\mathrm{R}^{2}$ means that the ability of the independent variables to explain the variation in the dependent variable is very limited. A value close to one means that the independent variables provide almost all the information needed to predict the variation in the dependent variable.

Based on table 3, the coefficient of determination for the independent variable is 0.070 . Thus, it can be concluded that $7 \%$ of the Earnings Management (DA) variable can be explained by the independent variables, namely Managerial Ownership, Institutional Ownership, Company Size, Leverage (DER), Profitability (ROE) and Sales Growth. The remaining $93 \%$ is explained by other variables outside the model which are not discussed in this study.

$\underline{\text { F-test and t-test }}$

The F-test is used to determine whether the independent variables together have a significant effect on the dependent variable.

Table 4. Result of F-test

\begin{tabular}{|c|c|c|}
\hline Sig. & F-statistic & F-table \\
\hline 0,000 & 4,588 & 2,131 \\
\hline
\end{tabular}

Based on the results of table 4 above, it can be concluded that the variables Managerial Ownership, Institutional Ownership, Company Size, Leverage (DER), Profitability (ROE) and Sales Growth simultaneously affect Earnings Management (DA). This is because the value of F count $>$ F table (4.588> $2.131)$ or significance $<0.05(0.000<0.05)$ so that Ho is rejected and $\mathrm{Ha}$ is accepted.

Table 5. Result of t-test

\begin{tabular}{|l|c|c|c|}
\hline \multicolumn{1}{|c|}{ Variable } & Sig. & t-statistic & t-table \\
\hline Managerial Ownership & 0,395 & $-0,852$ & $-1,969$ \\
\hline Institutional Ownership & 0,889 & $-0,140$ & $-1,969$ \\
\hline Firm Size & 0,932 & 0,085 & 1,969 \\
\hline Leverage (DER) & 0,904 & $-0,120$ & $-1,969$ \\
\hline Profitability (ROA) & 0,004 & 2,928 & 1,969 \\
\hline Sales Growth & 0,001 & 3,217 & 1,969 \\
\hline
\end{tabular}

Based on the results of the t-statistic test on Managerial Ownership, partially there is no significant effect on Earning Management (DA), this is because the value-t-count> -t-table (-0.852> -1.969) or significance $0.395>0.05$ so that Ho is accepted and H1 is rejected which stated that Managerial Ownership has a negative effect on Earning Management. The results of the research for the first hypothesis state that Managerial Ownership has no effect on Earning Management. The test results of managerial ownership on 
earnings management show an insignificant effect in a negative direction. This is because, in the sample of this study, the number of share ownership owned by managers is low so that there is a high probability that there is a conflict between the interests of the majority (controlling shareholder) and the minority. Managerial ownership has no effect on earnings management.

Based on the results of the t-statistic test on Institutional Ownership, partially there is no significant effect on Earnings Management (DA), this is because the value-t-count> -t-table (-0.140> -1.969) or significance $>0.05(0.889>0.05)$ Ho is accepted and H2 is rejected, which states that Institutional Ownership has a negative effect on Earning Management. This is because in general, institutional investors do not play their role effectively as sophisticated investors who can supervise or monitor management performance to limit management in taking actions or policies that will impact earnings management actions. Institutional investors only carry out their role as transient investors (temporary owners of companies) who focus only on short-term profits, so that institutional ownership does not necessarily increase effective monitoring of management which will lead to reduced management policies in conducting earnings management. This result is in line with research conducted by Welvin and Arleen (2010), Dian Agustia (2013), Metta Kusumaningtyas (2012), Werner R Murhadi (2009) which states that institutional ownership does not affect earnings management. Although the number of shares owned by the institution does not guarantee that it will reduce earnings management practices. As a result, managers are forced to take actions that can increase short-term profits. Institutional ownership will make managers feel bound to meet the profit target of investors, so that even though the number of institutional ownerships increases or decreases, they will still tend to be involved in earnings manipulation. Besides, high institutional ownership is generally owned by the parent and or branch of the company itself, so in essence, although other companies have quite high shares, in fact, these shares are owned by one company.

Based on the results of the t-statistic test on firm size partially does not have a significant effect on earnings management (DA), this is because the value of t-count <t-table $(0.085<1.969)$ or significance $>0.05$ $(0.932>0.05)$ so that Ho is accepted and $\mathrm{H} 3$ rejected, which states that firm size has a positive effect on earnings management. The results of this study are also consistent with research conducted by Ayu, Elva, Anggita (2017) which states that company size is not the only consideration for investors in making investment decisions. However, other factors are more important to consider in making investment decisions, such as profitability, the company's future business prospects, and others. The nature of Indonesian investors is speculative and tends to have capital gains. Moreover, the condition of companies in Indonesia, with the size of their assets, does not guarantee a good company performance. The results of this study support the findings of research conducted by Gunawan, Darmawan, and Purwanti (2015) which found that company size does not affect earnings management.

Based on the results of the t-statistical test on Leverage (DER) partially does not have a significant effect on Earnings Management (DA) this is because the value t-count> -t-table (-0.120> -1.969) or significance> $0.05(0.904>0.05)$ so that Ho is accepted and $\mathrm{H} 4$ is rejected, which states that Leverage (DER) has a negative effect on Earning Management. The results of this study are in line with the research of Made (2007), Jao and Pagulung (2011), Wika (2011), and Elfira (2014) which state that leverage does not affect earnings management. This means that the level of leverage will not affect earnings management. According to Jao and Pagulung (2011), companies with high levels of leverage due to a large amount of total debt to total equity will face a high risk of default, namely the company is threatened with being unable to fulfill its obligations. This means that earnings management measures cannot be used as a mechanism to avoid this default. Fulfillment of obligations must be carried out and cannot be avoided by earning management.

Profitability (ROA) partially has a significant effect on Earning Management (DA) this is because the value of $\mathrm{t}$-count $>\mathrm{t}$-table $(2,928>1.969)$ or significance $<0.05(0.004<0.05)$ so that Ho is rejected and H5 is accepted which states that profitability (ROA) has a positive effect on earnings management. The results of 
this study support the research conducted by Guna and Herawaty (2010) which states that the greater the Return on Assets as a profitability ratio, the more efficient the use of assets is so that it will increase the profitability of the company. Big profits will attract investors because with large profits the company will have a higher rate of return. The higher this ratio, the better the asset productivity in obtaining net profit. So that Return on Assets can motivate management to perform earnings management, and it can also be said that Return on Assets has a positive effect on earnings management. The company's profits that are listed in the financial statements are a sensitivity for investors and potential investors to make the decision making. Therefore, companies that can provide good signals / deliver good information tend to attract potential investors and investors to invest in the company. In the signaling theory put forward by Jogiyanto (2014), information published as an announcement will provide a signal for investors in making investment decisions. When information is announced, market participants first interpret and analyze the information as a good signal (good news) or a bad signal (bad news). If the announcement of this information is considered a good signal, investors will be interested in trading shares, thus the market will react, which is reflected in changes in stock trading volume (Suwardjono, 2010). One type of information released by a company that can be a signal for parties outside the company is an annual report. Therefore, company managers will be motivated to carry out earnings management to convey good information to potential investors and investors.

Then the results of the t-statistic test on Sales Growth partially have a significant effect on Earning Management (DA) this is because the value of $t$-count $>t$-table $(3,217>1.969)$ or significance $<0.05(0.001$ $<0.05)$ so that Ho is rejected and H6 is accepted. which states that Sales Growth has a positive effect on Earnings Management. The results of this study are consistent with the research of Gu et al. (2005), Handayani and Rachadi (2009), and Sari (2015) which state that sales growth has a positive effect on earnings management. Companies with high sales growth rates also have the motivation to carry out earnings management to earn profits, when they are faced with problems to maintain profit trends and sales trends. This makes sales growth can affect the existence of earnings management.

\section{Conclusion and Reccomendations}

This study aims to analyze a model regarding the effect of Managerial Ownership, Institutional Ownership, Company Size, Profitability (ROA), Leverage (DER), and Sales Growth on Earnings Management in Manufacturing Companies in the Consumer Goods Industry Sector in 2015-2019 listed on the IDX. The theoretical framework and model will be used as the theoretical basis for this research. The phenomenon of earnings management is very interesting to research because it can provide an overview of the behavior of managers in reporting their business activities in a certain period, namely the possibility of the emergence of earnings management by managers by manipulating the company's profits to be higher, lower or always the same for several periods. because of certain motivations that encourage them to manage or manage financial data, especially reported earnings.

The population used in this study are all manufacturing companies listed on the Indonesia Stock Exchange (BEI). Based on the list of shares on the IDX (2020), there are 193 manufacturing companies listed on the IDX. The sampling technique used in this study is non-probability sampling because the sampling technique does not provide equal opportunities for every element or member of the population to be selected as samples (Sugiyono, 2014). The type of non-probability sampling used in this study is purposive sampling because the sampling technique is based on certain considerations (Sugiyono, 2014). Certain considerations in determining the sample or respondent in this study are manufacturing companies that are consistently listed on the IDX website during the 2015-2019 period and companies that have managerial and institutional share ownership data respectively during the observation period. The number of samples (N) used was 285 data 
obtained from 57 manufacturing companies with a 5-year study period. The results of this study are expected to be able to answer the problem formulations in this study.

Based on data processing carried out to obtain the final result of the proposed hypothesis, there are two hypotheses accepted and four other hypotheses rejected. The results of the study state that Managerial Ownership, Institutional Ownership, Company Size and Leverage (DER) do not affect earnings management. This is supported by research by Mediastuty and Machfoeds (2003), Welvin and Arleen (2010), Dian Agustia (2013), Metta Kusumaningtyas (2012), Werner R Murhadi (2009), Gunawan, Darmawan, and Purwanti (2015); Ayu, Elva, Anggita (2017). Then the results of further research state that profitability (ROE) has a positive influence on earnings management. The results of this study support the research conducted by Guna and Herawaty (2010) which states that the greater the Return on Assets as a profitability ratio, the more efficient the use of assets is so that it will increase the profitability of the company. Big profits will attract investors because with large profits the company will have a higher rate of return. The higher this ratio, the better the asset productivity in obtaining net profit. So that Return on Assets can motivate management to perform earnings management, and it can also be said that Return on Assets has a positive effect on earnings management. Furthermore, the results of the study state that Sales Growth has a positive effect on Earning Management. The results of this study are consistent with the research of Gu et al. (2005), Handayani and Rachadi (2009), and Sari (2015) which state that sales growth has a positive effect on earnings management. Companies with high sales growth rates also have the motivation to carry out earnings management to earn profits, when they are faced with problems to maintain profit trends and sales trends. This makes sales growth can affect the existence of earnings management. Here are some recommendations for further research so that it can be more comprehensive. The following are some recommendations that can be given, namely:

- Future research is expected to examine other independent variables that can explain Earnings Management with a greater R2 presentation.

- Future research is expected to use a sample of manufacturing companies outside Indonesia so that we can find out the effect of variables on earnings management on an international scale.

- Future research can use data that is not too extreme in the mean.

- Future research should provide a more theoretical basis.

- Further research is expected to use different proxies, especially leverage proxies. It is recommended to use proxies that are unlikely to have negative values on the liver ratio.

- Future studies are expected to examine using moderating variables.

\section{References}

Adyani, L. R., \& Sampurno, D. D. (2011). ANALISIS FAKTOR-FAKTOR YANG MEMPENGARUHI PROFITABILITAS (ROA). Jurnal Dinamika Ekonomi.

Ali, S., Salleh, N., \& Hassan, M. (2008). Ownership structure and earnings management in Malaysian listed companies: the size effect. Asian Journal of Business and Accounting, 89-116.

Asih, P. (2015). Faktor-faktor yang Mempengaruhi Praktik Manajemen Laba. Thesis.

Ball, R., Robin, A., \& Wu, J. (2003). Incentives versus Standards: Properties of Accounting Income in Four East Asian Countries. Journal of Accounting \& Economics, 36, 235-270.

Christie, A. A., \& Zimmerman, J. L. (1994). Efficient and Opportunistic Choices of Accounting Procedures: Corporate Control Contests. The Accounting Review, 539-566.

Dechow, P., Sloan, R., \& Sweeney, A. (1996). Causes and Consequences of Earnings Manipulaton: An Analysis of Firms Subject to Enforcement Actions by the SEC Contemporary Accounting Research., 1-36.

Fahmie, A. (2018, 8 13). Pengaruh Profitabilitas, Leverage, Struktur Kepemilikan, Pertumbuhan Penjualan Dan Komisaris Independen Terhadap Manajemen Laba (Studi Empiris Pada Perusahaan Industri Barang Konsumsi yang Terdaftar di BEI Tahun 2012-2014). Jurnal Ilmiah Akuntansi Kesatuan, 6 no.2.

Fajrian, H. (2020, Febuari 20). TPS Food Sajikan Ulang Lapkeu 2017, Rugi Membengkak Jadi Rp 5 Triliun Artikel ini telah tayang di Katadata.co.id dengan judul "TPS Food Sajikan Ulang Lapkeu 2017, Rugi Membengkak Jadi Rp 5 Triliun" 
,https://katadata.co.id/berita/2020/02/12/tps-food-saji. Diambil kembali Katadata.co.id: https://katadata.co.id/berita/2020/02/12/tps-food-sajikan-ulang-lapkeu-2017-rugi-membengkak-jadi-rp-5-triliun

Fakhruddin, H. M. (2008). Istilah Pasar Modal A-Z. Jakarta: Elex Media Komputido.

Ghazali, Imam, 2016, “Aplikasi Analisis Multivariat Dengan Program IBM SPSS 23”, Cetakan kedelapan, Universitas Diponegoro, Semarang. Hal 156, 134, 138, 137, 116, 5, 103, 157.

Govindarajan, V. (2009). Management Control System. Jakarta: Salemba Empat.

Irawati, S. (2006). Manajemen Keuangan. Bandung: Pustaka.

Jao, R., \& Pagalung, G. (2011, November). "Corporate Governance, Ukuran Perusahaan dan Leverage terhadap Manajemen Laba Perusahaan Manufaktur Indonesia". Jurnal Akuntasi \& Auditing, 8, 1-94.

Jensen, M., \& Meckling, W. (1976). Theory of The Firm: Manajerial Behavior, Agency Cost and Ownership Structure. Journal of Financial Economics, 3, 305-360.

Kennedy. (2010). Faktor- faktor yang Mempengaruhi Struktur Modal pada Perusahaan Real Estate and Property yang Go Public Di Bursa Efek Indonesia. Jurnal.

Kouki, M., Abderrazek, E., Hanen, A., \& Slim, S. (2011). Does Corporate Governance Constrain Earnings Management? Evidence from U.S. Firms. European Journal of Economics, Finance and Administrative Sciences, 35, 58-71.

Lafond, R., \& Roychowdhury, S. (2008). Managerial Ownership and Accounting Conservatism. Journal of Accounting Research, 101135 .

Mahawyahrti, P. T., \& Budiasih, I. A. (2016). Assymetry Information, Leverage and Firm Size on Earnings Management. Jurnal Ilmiah Akuntansi dan Bisnis, Vol. 11, No. 2, Juli 2016, 100.

Muliati, N. K. (2011). Pengaruh Asimetri Informasi dan Ukuran Perusahaan pada Manajemen Laba di Perusahaan Perbankan yang Terdaftar di Bursa Efek Indonesia. Tesis.

Nasution, M., \& Setiawan, D. (2007). Pengaruh Corporate Governance Terhadap Manajemen Laba di Industri Perbankan. Simposium Nasional Akuntansi X, Makassar.

Nirmalasari, I. (2020, Febuari 14). Mantan direktur Tiga Pilar Sejahtera (AISA) resmi jadi tahanan. Diambil kembali dari Kontan.co.id: https://investasi.kontan.co.id/news/mantan-direktur-tiga-pilar-sejahtera-aisa-resmi-jadi-tahanan

Priyatno, Duwi, 2013, "Mandiri Belajar Analisis Data Dengan SPSS”, Yogyakarta: Media Kom. Hal 25, $30,9,40$.

Priyatno, Duwi, 2014, "SPSS 22 Pengolah Data Terpraktis", Edisi 1, Yogyakarta: ANDI. Hal: 94, 103, 106.

Puspitasari, I. (2020, Juli 06). Belum cabut suspensi, BEI minta Tiga Pilar (AISA) gelar public expose insidentil. Diambil kembali dari Kontan.co.id: https://investasi.kontan.co.id/news/belum-cabut-suspensi-bei-minta-tiga-pilar-aisa-gelar-public-expose-insidentil

Santoso, Singgih, 2013, "Menguasai SPSS 21 di Era Informasi”. PT. ELEK Media Komputindo. Jakarta. Hal: 347,354

Savitri, D., \& Priantinah, D. (2019). The Effect of Leverage on Earnings Management with Corporate Governance as Moderating Variable Various Industries Manufacturing Companies Listed on Indonesia Stock Exchange 2013-2016. JURNAL NOMINAL / VOLUME VIII NOMOR 2 / TAHUN 2019.

Schipper, K. (1989). Earnings Management. Commentary on Earnings Management, 91-102.

Scott, W. (2000). Financial Accounting Theory 2nd Edition. Canada: Prentice Hall.

Solihin, I. (2009). Pengantar Management. Jakarta: Erlangga.

Sukirni, D. (2012). KEPEMILIKAN MANAJERIAL, KEPEMILIKAN INSTITUSIONAL, KEBIJAKAN DEVIDEN DAN KEBIJAKAN HUTANG ANALISIS TERHADAP NILAI PERUSAHAAN. Accounting Analysis Journal.

Suparsada, N. D., \& Putri, I. A. (2017). PENGARUH PROFITABILITAS, REPUTASI AUDITOR, UKURAN PERUSAHAAN, DAN KEPEMILIKAN INSTITUSIONAL TERHADAP AUDIT DELAY PADA PERUSAHAAN MANUFAKTUR. E-Jurnal AkUntansi Universitas Udayana, 60-87.

Suwito, E., \& Herawaty, A. (2005). Analisis Pengaruh Karakteristik Perusahaan terhadap Tindakan Perataan Laba yang Dilakukan Oleh Perusahaan yang Terdaftar di Bursa Efek Indonesia. Simposium Nasional Akuntansi VIII.

Trihendradi, Cornelius, 2013, "Langkah Mudah Menguasai Analisis Statistik Menggunakan SPSS 21", Yogyakarta: ANDI. Hal:154.

Wareza, M. (2019). Tiga Pilar dan Drama Penggelembungan Dana. Jakarta: CNBC Indonesia.

Watts, R. L., \& Zimmerman, J. L. (1990, January). Positive Accounting Theory: A Ten-Year Perspective. The Accounting Review, 65, $131-156$.

Watts, R., \& Zimmerman, J. (1968). Positive Accounting Theory. New York: Prentice Hall.

Widarjono, Agus, 2015, “Analisis Multivariate Terapan Dengan Program SPSS, AMOS, dan SmartPLS". Edisi II, UPP STIM YKPN, Yogyakarta. Hal 71.

Widyastuti, T. (2009). "Pengaruh Struktur Kepemilikan dan Kinerja Keuangan Terhadap Manajemen Laba: Studi Pada Perusahaan Manufaktur di BEI". Jurnal Maksi, 9 No. 1, 30-41.

Widyastuti, T. (2009). "Pengaruh Struktur Kepemilikan dan Kinerja Keuangan Terhadap Manajemen Laba: Studi Pada Perusahaan Manufaktur di BEI". Jurnal Maksi, Vol 9 No. 1, 30-41.

Wild, J. J., \& Subramanyam, K. (2009). Financial Statement Analysis 10th Edition. The USA: McGraw-Hill Companies, Inc.

Yendrawati, Y. (2017, 02 08). Pengaruh Dewan Komisaris Independen, Komite Audit, Kepemilikan Manajerial, dan Kepemilikan Institusional terhadap Manajemen Laba. Jurnal Entrepreneur dan Entrepreneurship, 4 No. 1,2.

Yogiyanto. (2007). Teori Portofolio dan Analisis Investasi. 